\title{
The Difficulties Faced by Foreigners in Learning Indonesian at Puri Bahasa Indonesia
}

\author{
Emma Lutfiana \\ P.T. Vads Indonesia \\ emmalutfiana2@gmail.com
}

\begin{abstract}
Many foreigners are working in Indonesia, leading to many of them learning Indonesian to facilitate their workplace communication. Puri Bahasa Indonesian language course in Yogyakarta provides customized, unique approaches in teaching Indonesian language to foreigners by combining theories and practices. The aim of this research is discussing the types of difficulties faced by foreign learners in learning Indonesian at Puri Bahasa Indonesia. Literature study and field study were conducted in collecting the data. Direct observations and interviews were also conducted to confirm the data and information collected about the difficulties faced by foreign learners in learning Indonesian language at Puri Bahasa Indonesia. The results of the study showed foreign learners face difficulties such as memorizing, pronouncing Indonesian vocabulary and understanding the usage of prefix and suffix in Indonesian.
\end{abstract}

Keywords: BIPA, Indonesian, language teaching, vocabulary, theoretical and practical approaches

\section{INTISARI}

Banyak orang asing bekerja di Indonesia, yang membuat banyak dari mereka belajar bahasa Indonesia untuk mempermudah komunikasi mereka di tempat kerja. Lembaga Kursus Bahasa Indonesia Puri Bahasa menyediakan pendekatan yang unik dan dimodifikasi untuk mengajarkan Bahasa Indonesia pada orang asing melalui pendekatan teoritis dan praktis. Tujuan penelitian ini adalah untuk mendiskusikan jenis-jenis kesulitan yang dihadapi oleh orang asing dalam mempelajari Bahasa Indonesia di Puri Bahasa Indonesia. Pengumpulan data dilakukan melalui studi pustaka dan studi lapangan. Observasi langsung dan wawancara juga diadakan untuk mengkonfirmasi data dan informasi yang telah dikumpulkan mengenai kesulitan-kesulitan yang dihadapi oleh orang asing ketika belajar bahasa Indonesia di Puri Bahasa. Hasil studi menunjukkan bahwa orang asing mengalami kesulitan dalam mengingat, melafalkan kosakata, dan memahami penggunaan prefiks dan sufiks dalam bahasa Indonesia.

Kata kunci: BIPA, bahasa Indonesia, pengajaran bahasa, kosakata, pendekatan teoretis dan praktis

\section{Saran sitasi:}

Lutfiana, E. (2021). The Difficulties Faced by Foreigners in Learning Indonesian at Puri Bahasa Indonesia. JLA (Jurnal Lingua Applicata), 4(2), 89-98. 


\section{INTRODUCTION}

Since MEA (Masyarakat Ekonomi Asean) or AEC (Asian Economic Community) was launched by the end of 2015, workers from around the world have had more access to work in other nations, including Indonesia. In its turn, the enactment of AEC will open the opportunity of various job vacancies for foreigners in Indonesia. Hence, foreigners who have related interest to learn Bahasa Indonesia will come to the land of origin of the language since to excel their working performance in Indonesia, definitely the foreigners should have an adept skill in communicating in Bahasa Indonesia to further adapt their expertise with the social, local culture of Indonesia. Moreover, Permenaker (Peraturan Menteri Tenaga Kerja) No. 12 year 2013 in Indonesia has stipulated that one of conditions for foreigners who work in Indonesia is to be able to speak in Indonesian. Although it was revised in June 2015 by the issuance of Permenaker No. 16 year 2015 which states that foreigners who work in Indonesia actually do not have to master Indonesian, however, fluency in Bahasa Indonesia might make their social communication much more meaningful and easier, which in turn will help strengthening their business network with local stakeholders or fellow businessmen. Therefore, before starting to work in Indonesia, a number of foreigners spend their time learning Bahasa Indonesia first.

One of Indonesian language courses in Indonesia is Puri Bahasa Indonesia in Yogyakarta. Puri Bahasa Indonesia is one of language courses that provide BIPA (Bahasa Indonesia untuk Penutur Asing, or Indonesian for Foreign Speakers) courses by combining theory and practice in learning Bahasa Indonesia. Because learning theories of language is not enough, a real practice to complete the process of learning Bahasa Indonesia is needed. According to Biggs and Tefler, "teaching, like any professional practice, requires the integration of two different kinds of knowing: knowing that and knowing how. The first kind of knowing - knowing that is declarative knowledge, but the knowing how is procedural knowledge" (1987: 1). In addition, according to Leberman, McDonald and Doyle, when learning in one context improves learning or performance in another context then it is called positive transfer (2006: 4). Related to the concept of learning a language by combining theoretical and practical knowledge, learning the theory first is known to create a better practical performance. Consequently, in order to compete with other Indonesian language courses in ensuring a high quality graduates, Puri Bahasa Indonesia provides a different Indonesian language learning which is packaged in an appropriate combination of approaches, namely the theoretical and practical ones. However, several pedagogical challenges would definitely occur to the native speakers in their process of learning Bahasa Indonesia, as the students might come from a very different language system and environment. This study therefore aims to define the difficulties experienced by the native 
speakers in learning Bahasa Indonesia at Puri Bahasa Indonesia. This study also aims to elaborate more on the approaches used in teaching Bahasa Indonesia for foreign learners.

\section{RESEARCH METHOD}

There are two methods for collecting data on learners' difficulties in learning Bahasa Indonesia as well as the approaches in teaching Bahasa Indonesia for foreign learners at Puri Bahasa Indonesia, namely field study and literature study. Direct observation and interviews in field study were conducted to obtain some data and information about the profile of Puri Bahasa Indonesia and the approaches employed in teaching Bahasa Indonesia for foreign learners at Puri Bahasa Indonesia. Dra. Sri Ningsih as the owner and the leader of Puri Bahasa and the teachers who teach Bahasa Indonesia for foreigners were interviewed. Literature study was also conducted by reviewing some references which are relevant to the topic to support the theoretical foundation of the study. Data which had been collected were organized and grouped based on the objectives of the study. Furthermore, all the data were interpreted systematically to answer the research question.

\section{RESULT AND DISCUSSION}

\section{A. Difficulties Faced by the Learners}

Data analysis has revealed that Indonesian learners were struggling with vocabularies, especially in memorizing and pronouncing words in Bahasa Indonesia.
Learning vocabulary is essential to master a new language, because it becomes a foundation for learners to learn how to speak, listen, read and write (Richards and Renandya, 2002: 255). Regarding the definition of vocabulary, according to Hatch and Brown (1995: 1), it is "a set of words for a particular language that individual speakers of language might use." Schmitt and McCarthy (1997) emphasized the importance of vocabulary, which is to create a meaningful communication in second/foreign language. Therefore, there are several key points in mastering vocabularies, which is knowing: 1) what the word means, 2) how to write the word, 3) how to speak the word, 4) what the grammatical behaviour the word has, 5) the collocation, register, association, and frequency of the word.

However, learning vocabulary is not necessarily an easy task to do for some individuals. As specified by Thornbury (2002: 27), as well as by Gower, Philips and Walter (1995: 143), there are several factors that make it difficult to learn:

1) Difficult pronunciation

Words that are difficult to pronounce are more difficult to learn.

2) Mismatches of pronunciation or spelling Sounds-spelling mismatches are likely to be the cause of errors, either of pronunciation or of spelling, and can contribute to a word's difficulty. While most English spelling is relatively lawabiding, there are also some apparent irregularities. Words that contain silent letters are particularly problematic: 
foreign, listening, headache, climbing, bored, honest, cupboard, muscle, etc. The spelling of many Indonesian words can cause problems for students who speak languages with a very regular spelling system. Particular spelling patterns can also cause confusion where the pronunciation is concerned. For example, it is easy to understand why many students confuse the meaning, spelling and pronunciation of these words: apel, apel, hujan, ujian.

3) Long and complex words seem to be more difficult to learn than short ones.

4) Grammatical structure associated with the word in second/foreign language (L2) which is different from learners' first language (L1). In contrast, according to Gower, Philips and Walter (1995), similar words between L1 and L2 in their form and meaning might as well cause some confusion.

5) The meaning of two or more words is overlapping, which is confusing for learners. Understanding words collocation can also become an overwhelming strain for some learners. For example, kencang in Indonesian can be used to express fast or tight.

6) A wider range of the word's context might be easier to perceive compared to its synonym with a narrower range, such as thin compared to skinny or slim. Uncertainty as to the connotations of some words may also cause problems, such as propaganda has negative connotations in English, but its equivalent may simply mean publicity.
On the other hand, eccentric does not have negative connotations in English, but its nearest equivalent in other languages may be deviant.

7) The uncertainty of the correct connotation of the word might also cause some confusion for learners. Words in Indonesian kurus and langsing both mean thin (body shape), but have different connotations depending on a particular attitude the speaker wants to convey.

8) Simple word versus idiomatic word or expression, such as silat lidah or adu mulut which means debate or argue. Compound words are notoriously difficult for learners of Indonesian because they are made up of simple words (often totally unrelated words).

9) Collocation of some words can also cause difficulty. For example, people are terluka or cedera but things are rusak, and we can say a angin kencang and ikatannya kencang, but it's angin sepoi not angin lambat and ikatan renggang not ikatannya lambat.

10) When to use vocabulary appropriately is also problematic. Some words and expressions are restricted to use in particular contexts (for example, we can use mendekati to mean almost in Dia mendekati ajal. But other verbs cannot be used with ajal although it means similarly to mendekati, such as menguntit). Also it is important that students know whether the word or phrase is informal or formal. 
In the process of learning a new language, there are various types and levels of difficulties that the learner experiences. Based on the observation at the classes of foreigners who were learning Bahasa Indonesia and the interviews with the director and teachers of Bahasa Indonesia in Puri Bahasa Indonesia, it is concluded that the learners mainly experienced difficulties in memorizing and pronouncing Indonesian vocabulary. Meanwhile, based on the interviews with those learners, they stated that they also experienced difficulties in understanding the usage of prefix and suffix in Indonesian language. Those difficulties experienced are further elaborated below:

\section{a. Memorizing Indonesian vocabulary}

The common difficulty that the learners experience in the beginning of the lesson is memorizing the vocabulary. When the foreigners have targeted themselves a considerable goal in learning Bahasa Indonesia, they would require an extra set of efforts, one of which is memorizing the Indonesian vocabulary. This difficulty arose because they come from different country and speak different languages, thus memorizing the vocabulary of Bahasa Indonesia were a completely new challenge for them.

In addition, the difficulty of memorizing the vocabulary of Bahasa Indonesia was not caused solely by unfamiliarity. There is another factor that gave the learners hard times in memorizing vocabulary, namely the age of the learners.
The foreign learners who learn Bahasa Indonesia in Puri Bahasa Indonesia came from various ranges of age. The range of age of the foreign learners is from 20-50 years old, although much older learners were also present. This might contribute to the added difficulties experienced by the learners as they, especially the elderly ones, took longer time to memorize the vocabularies than the time allocated in the syllabus.

One of the factors that also contribute to this difficulty, according to the interview with the foreign learners, is the vocabularies in Bahasa Indonesia are written differently from how they are spoken. Since most of the learners speak English as their main language of communication, they tend to apply English pronunciation system. This indeed hindered how they memorized the vocabularies as often the learners pronounced the words that they already learned differently from how they should be. As the two languages developed very differently since their creations in the past, it is obvious that between English and Bahasa Indonesia there is no sound similarity that the learners could take hold as a means of memorization.

The other factor that added the difficulty to memorize is also the large number of vocabulary words that students need to learn. With the limited time of course the foreign students have, the number of vocabulary they could fluently master will also be limited. Therefore the teachers of Puri Bahasa Indonesia tend to give them necessary vocabularies that are 
significant to help their survival of communication in proper Bahasa Indonesia.

\section{b. Pronouncing the vocabulary}

Besides the difficulty in remembering vocabulary, another difficulty the foreign learners experienced is pronouncing the vocabulary. The factor that caused the difficulty to the learners to pronounce Indonesian vocabulary is their own mother tongue. Since the learners of the Puri Bahasa Indonesia are foreign learners who mainly come from English speaking countries, the language that they use for most of their time is English. For several learners, English is their mother tongue. Because they use English, of which some sounds are aspirated (such as th- in the or there), they experienced difficulties in pronouncing vocabulary in Bahasa Indonesia as aspirated sound is almost nonexistent in Bahasa Indonesia. It causes the learners hard to pronounce Indonesian vocabulary the way it should be in Bahasa Indonesia.

There are other two factors that also contribute to this difficulty. The first one was the limitations of sources of information about words, either its origin or its formation. Some learners stated that they could understand the various inflection systems in Bahasa Indonesia better when they have the information of how the words came from. However this was not easily resolvable as the teachers know the vocabularies and their meanings for how they are. The other one was the complexity of word knowledge. The learners were made aware that knowing a word involves much more than knowing its dictionary definition; they also have to understand its various possible uses in different social contexts. Without this kind of fluency, they found it hard to reach a fluid, comfortable communication with the native speakers of Bahasa Indonesia.

c. Understanding the usage of prefix and suffix in Indonesian vocabulary

In addition to difficulties in memorizing and pronouncing the vocabulary of Bahasa Indonesia, the foreign learners also face difficulty in understanding the usage of prefixes and suffixes in Indonesian vocabulary. In English vocabulary, there is no prefix and suffix in the vocabulary as Bahasa Indonesia does in its vocabulary. Therefore, the foreign learners need to adjust with the inflections of verbs along with prefixes and suffixes when learning Bahasa Indonesia. As an example, the word luka becomes melukai and terluka. The classification of the word luka is a noun, but if a prefix and suffix $m e-i$ is added, it becomes a verb. Meanwhile if it is added only with terprefix, the word becomes an adjective (terluka). However, those rule is not the same for other words. Another example is the word makan. If the word makan is added with a prefix and suffix $m e-i$, the word becomes memakani, but the word itself does not exist. It only needs the prefix me- to become a verb, different from how other verb suffixation works. The numerous exception in the suffixation system alone 
made the foreign learners feel confused in understanding the usage of prefix and suffix because not all Indonesian vocabulary have the same rule on the addition of prefix and suffix. These difficulties was also added with the minimum understanding of the grammatical rules of using the inflected words.

In summary, the common difficulties that the foreign learners face while learning Bahasa Indonesia are (1) memorizing the vocabulary, pronouncing Indonesian vocabulary, and (3) understanding the usage of prefix and suffix in Bahasa Indonesia. It can be concluded that the main factor that contributes to the difficulties are (1) the unfamiliarity of the learners towards the grammatical system of Bahasa Indonesia, and (2) the learners' mastery in their own mother tongue, which are mostly English, that tampered in their process of learning Bahasa Indonesia.

\section{B. Approaches in Teaching Bahasa Indonesia}

Puri Bahasa Indonesia is considered a professional Indonesian language course because it has many experiences in teaching Indonesian language to foreign learners since 1992. According to the interview with the owner and teachers of Puri Bahasa Indonesia, the approaches in teaching Bahasa Indonesia for foreign learners that are applied in Puri Bahasa Indonesia commonly are: covering the stage in a lesson, theory and practice lesson. Every teaching process needs to complete three stages, namely the preparation, the main teaching activity, and the closing. The preparation covers three sub stages: review of previous lesson, lead in, and elicitation. The main teaching activity also covers three sub stages: presentation with concept checking, controlled practice or drilling, and free production. Meanwhile, the last stage covers the process of reinforcement, by giving additional exercises in order to get the learners understand and remember the materials.

The teaching approaches employed at Puri Bahasa Indonesia are the combination between theory and practice in classes. There are two theory classes and two practice classes. The stages of the lesson are applied in the theory lesson in order to get the learner to have the strong basic theory of Bahasa Indonesia, so the learner would be ready to do the practice with the real condition in practice. It is because the practice lesson is the implementation class in practicing the theory of Bahasa Indonesia from theory lessons. Therefore, the combination of those approaches in teaching Bahasa Indonesia for foreign learners at Puri Bahasa Indonesia is appropriate. Furthermore, the two lessons which are theory and practice lessons have the same goal, which is to teach Bahasa Indonesia to foreign learners and to get them having a good knowledge of Indonesian culture. However, those lessons have different focuses. The focus of theory lessons is to get the learners to have the strong basics of Bahasa Indonesia in theory, such as spelling, pronunciation, 
grammatical use, as well as the appropriate usage of words. During the theory lesson, learners were taught the theory of how to start the conversation, how to ask for direction to certain places, how to ask and give an opinion, etc. Meanwhile the focus of practice lessons is to get the learners to do the real practice in the real world; that is during the cooking class and the trip class. During these classes, the teachers encouraged learners to practice what they have been taught in theory class, such as asking and giving an opinion about the food they made, the historical places they visited, asking and bargaining the price, asking directions to a place, etc. The topic of these speaking practices was customized with the places they visited. During the trip class, learners were encouraged as well to make conversation with local people. Therefore, they practiced speaking in Bahasa Indonesia and at the same time explored more about Indonesian culture. They could practice some Indonesian manners as well, such as what to do when passing the elder people. These kinds of knowledge were important since they spent some time in Indonesia during their study. Thus, the theory lesson and practice lesson are the combination of good approaches in teaching Bahasa Indonesia because the learners do not only master the knowledge in theory, but also to have the real practice in the real condition. It can be assumed as well that even though theory and practice lessons have different focuses, the purpose of those lessons are similar, in a way that they were designed to teach foreign learners Bahasa Indonesia and to make them able to have a good knowledge of Indonesian culture.

The Indonesian teachers also use the element of Indonesian culture as one of the teaching approaches in order to help the learners understand the materials. In teaching vocabulary, for example, teachers picked up some vocabularies from passages about Indonesian cultures, such as Yogyakarta palace, wooden puppet, or traditional dance. When learners found some difficult vocabularies, the teachers would explain how to pronounce them followed by the meaning of those vocabularies. Learners were required to repeat the pronunciation and explain the meaning using their own words in Bahasa Indonesia. The teachers would then check learners' comprehension by inviting learners to do more practice by making some sentences using the vocabularies.

\section{CONCLUSION}

Based on the theories, the findings and the analysis, the present study arrives at the conclusions about the problems or difficulties faced by the foreign students in learning the vocabulary of Bahasa Indonesia at Puri Bahasa Indonesia. The difficulties faced by the students were that almost all of the students have difficulties in: (1) pronouncing the Indonesian words, (2) writing and spelling, and (3) the different grammatical forms of a word known as inflections. These are the causes of difficulties experienced by foreign students in Puri Bahasa in learning Indonesian vocabulary. In addition, in 
learning Indonesian language, foreign learners experience difficulties in forms of memorizing, pronouncing the Indonesian vocabulary and understanding the usage of prefix and suffix in Indonesian language, choosing the appropriate meaning of the words and also still having confusion in using the word based on the context. Moreover, the students are also still confused when they find words or expressions that are idiomatic.

Based on the result of observation, several factors that caused students' difficulties in learning vocabulary were: (1) the written form of Indonesian is different from the spoken form, (2) the amount of words that students need to learn is relatively numerous, (3) the limitations of sources of information about words, (4) the complexity of word knowledge because knowing a words involves much more than knowing only its definition in dictionary, (5) the lack of understanding of grammatical of the words, and (6) the incorrect pronunciation is often caused by the lack of sound similarity between Indonesian and the students native language. Those difficulties are caused by their own factors. However, the basic factor that causes the foreign learners to experience the difficulty is the unfamiliarity the learners have since there are differences in the grammatical structures between Bahasa Indonesia and English. In short, teaching Indonesian language to foreign learners by combining the two approaches theory and practice is a good strategy in order to facilitate the learners to minimize the difficulties that the learners face during the Indonesian language learning process. The difficulties in learning Indonesian language such as memorizing, pronouncing the Indonesian vocabulary and understanding the usage of prefix and suffix in Indonesian language can be minimized by implementing the approaches in teaching Indonesian language at Puri Bahasa Indonesia, which get the learners to not only learning the theory but also having some real practices.

As a Bahasa Indonesia course, Puri Bahasa Indonesia has applied customized approaches in teaching Bahasa Indonesia to foreign learners. There is one recommendation which is about a program for the learners in improving their speaking ability. The program can be a speaking club or a discussion among the learners who have the different level. By creating this program it is expected that the learners can improve their speaking skills and have a space in sharing their experience in learning at Puri Bahasa Indonesia.

\section{REFERENCES}

Biggs, J. B., Telfer, R. (1987). The Process of Learning. Prentice-Hall of Australia Pty, Ltd.

Brown, H. D. (2001). Teaching by Principle: An Interactive Approach to Language Pedagogy. Pearson Longman. Gower, R., Phillips, D., Walters, S. (1995). Teaching Practice Handbook. Heinemann. 
Hatch, E., Brown, C. (1995). Vocabulary, Semantics, and Language Education. Cambridge University Press.

Leberman, S., McDonald, L., Doyle, S. (2006). The Transfer of Learning: Participants' Perspectives of Adult Education and Training. Gower Publishing Limited.

Ministry of Labor of the Republic of Indonesia. (2015, June). Peraturan Menteri Ketenagakerjaan Republik Indonesia Nomor 16 Tahun 2015. Retrieved on June 19, 2020 from https://tkaonline.kemnaker.go.id/pdf/PERMEN_1 6_TAHUN_2015.pdf

Ministry of Labor and Transmigration of the Republic of Indonesia. (2013,
December). Peraturan Menteri Tenaga Kerja dan Transmigrasi Republik Indonesia, Nomor 12 Tahun 2013. Retrieved on June 19, 2020 from https://peraturan.bkpm.go.id/jdih/userfil es/batang/Permentenkertrans_12_2013. pdf

Richards, J.C., Renandya, W.A. (Eds.) (2002). Methodology in Language Teaching: An Anthology of Current Practice. Cambridge University Press.

Schmitt, N., McCarthy, M. (1997). Vocabulary: Description, Acquisition and Pedagogy. Cambridge University Press.

Thornbury, S. (2002). How to Teach Vocabulary. Pearson Longman. 